\title{
Pengaruh Profitabilitas, Kebijakan Hutang, Degree Of Operating Leverage Terhadap Nilai Perusahaan
}

\author{
Aghlul Jannatun ${ }^{1^{*}}$, Yuli Chomsatu ${ }^{2}$ \\ Universitas Islam Batik Surakarta \\ *Korespondensi: aghlul.jannatun@gmail.com
}

\begin{abstract}
In the face of the increasingly rapid development of the economic sector in Indonesia, companies are thinking of finding ways that the value of existing companies can be useful in the future. This study was conducted to examine the effect of profitability, debt policy and dol (Degree of Operating Leverage) on the value of companies listed in the Jakarta Islamic index (JII) during the period June 2016 - May 2019. The population of this study is companies listed in the Jakarta Islamic Index ( JII). Sampling is determined using sample purposiv. There are 30 samples in this study based on predetermined criteria. Based on the research that has been done, the results obtained show that profitability, debt policy and dol significantly influence the value of the company. The results of this study were carried out by regression testing which showed that if profitability, debt and dol policies were higher, it would increase the value of the company. The benefits of this study are as one of the considerations of investors in determining decisions when making investment decisions in a company.
\end{abstract}

Keywords: Profitability, dol, policy, debt, company value.

\begin{abstract}
Abstrak
Dalam menghadapi perkembangan zaman yang semakin cepat pada sektor perekonomian di Indonesia membuat perusahan berfikir untuk menemukan cara agar nilai perusahaan yang ada saat ini bisa bermanfaat untuk masa yang akan datang. Penelitian ini dilakukan untuk menguji pengaruh profitabilitas, kebijakan hutang dan dol (Degree of Operating Leverage ) terhadap nilai perusahaan yang terdaftar di Jakarta Islamic index (JII) selama periode Juni 2016 - Mei 2019. Populasi penelitian ini adalah perusahaan yang terdaftar di Jakarta Islamic Index (JII).Pengambilan sampel ditentukan dengan menggunakan purposiv sampel. Terdapat 30 sampel dalam penelitian ini berdasarkan kriteria yang telah ditentukan. Berdasarkan penelitian yang telah dilakukan,hasil yang didapat menunjukkan bahwa profitabilitas,kebijakan hutang dan dol berpengaruh signifikan terhadap nilai perusahaan. Hasil penelitian ini dilakukan dengan pengujian regresi yang menunjukkan jika profitabilitas, kebijakan hutang dan dol semakin tinggi akan meningkatkan nilai perusahaan. Manfaat dari penelitian ini adalah sebagai salah satu pertimbangan investor dalam menentukan keputusan saat akan melakukan pengambilan keputusan investasi di suatu perusahaan.
\end{abstract}


Kata Kunci: Profitabilitas, DOL, Kebijakan, Hutang, Nilai Perusahaan.

\section{A. Pendahuluan}

Nilai perusahaan yang optimal dapat dicapai dengan melakukan salah satu cara yaitu menerapkan manajemen keuangan dalam perusahaan, setiap keputusan keuangan yang diambil akan berdampak pada keputusan perusahaan yang lain. Menurut (Analisa, 2011) Profitabilitas dapat mempengaruhi nilai perusahaan,jika profitabilitas yang ada pada perusahaan meningkat maka pihak - pihak yang berkepentingan antara lain supplier, kreditur, pemegang saham kreditur, supplier,para investor akan melihat bagaimana perusahaan menghasilkan keuntungan atau laba dari hasil penjualan usaha dan investasi yang ada.

Berdirinya sebuah perusahaan tidak terlepas dari tujuan untuk menciptakan nilai bagi pemiliknya, dengan cara memaksimalkan kekayaan pemegang saham. Semakin tinggi nilai perusahaan menggambarkan semakin sejahtera pula pemiliknya (Wahyudi dan Pawestri, 2006). Nilai perusahaan tercermin dari harga sahamnya. Mardiyati, et,al (2012) berpendapat bahwa nilai perusahaan yang go public di pasar modal tercermin dalam harga saham perusahaan, sedangkan nilai perusahaan yang belum go public nilainya terealisasi apabila perusahaan akan dijual, prospek perusahaan, risiko saham, lingkungan usaha dan lainlain. Pembentukan harga saham disebabkan adanya permintaan dan penawaran atas saham yang disebabkan adanya banyak faktor. Hal ini yang mendasari penelitian mengenai faktor-faktor apa saja yang dapat menyebabkan penurunan dan peningkatan harga saham sebagai cerminan dari nilai perusahaan. Variabel yang diduga mempengaruhi nilai perusahaan dalam penelitian ini antara lain: profitabilitas, operating leverage, dan likuiditas.

Penelitian yang dilakukan oleh Mahendra et al (2012) mendapati hasil bahwa profitabilitas berpengaruh signifikan, sedangkan variabel lain seperti likuiditas, dan leverage tidak signifikan terhadap nilai perusahaan. Namun, hasil yang berbeda ditunjukkan oleh Gusaptono (2010) bahwa rofitabilitas tidak signifikan terhadap nilai perusahaan. Anzlina (2011) mendapati keadaan yang bertentangan dengan hasil sebelumnya mengenai likuiditas, bahwa likuiditas berpengaruh terhadap nilai perusahaan. Laba perusahaan merupakan elemen dalam penciptaan nilai perusahaan yang menunjukkan prospek perusahaan di masa mendatang. Sesuai dengan konsep signaling theory, profitabilitas akan menjadi sinyal dari manajemen yang menggambarkan prospek perusahaan berdasarkan tingkat profitabilitas yang terbentuk.

Berdasarkan penjelasan diatas maka masalah yang dapat dirumuskan dalam penelitian ini adalah : ( 1 ) apakah profitabilitas berpengaruh signifikan terhadap nilai perusahaan yang terdaftar di JII ? ( 2 ) apakah kebijakan hutang berpengaruh signifikan terhadap nilai perusahaan yang terdaftar di JII ? ( 3 ) apakah DOL(Degree of Operating Leverage ) berpengaruh signifikan terhadap nilai perusahaan yang terdaftar di JII ? 
dari perumusan masalah diatas maka yang perlu dilakukan dalam penelitian ini adalah menguji apakah profitasbilitas, kebijakan hutang dan dol berpengaruh signifikan terhadap nilai perusahaan yang terdaftar di JII.

\section{B. Tinjauan Pustaka}

\section{Teori Keagenan ( Agency Theory )}

(Meckling, 1976) mengatakan bahwa teori keagenan adalah teori perbedaan kepentingan antara prinsipal dan agen. Teori agensi didasarkan pada hubungan kontrak antara pemegang saham atau pemilik serta manajemen atau manajer. Dengan adanya teori ini, maka hubungan antara investor dan perusahaan memiliki tujuan masing - masing dalam pengambilan keputusan. Perusahaan dalam menjalankan bisnisnya menginginkan laba sedangkan investor menginginkan investasi yang dimiliki pada suatu perusahaan bisa memberikan keuntungan dengan resiko kerugian yang sangat sedikit, dengan adanya tingkat profitabilitas , kebijakan hutang dan dol akan menjadikan meningkatnya nilai perusahaan.

\section{Nilai Perusahaan}

Perusahaan didirikan dengan tujuan untuk meningkatkan nilai perusahaan . Peningkatan perusahaan bisa dilihat salah satunya berdasarkan penilaian yang tinggi dari pihak luar perusahaan terhadap aset perusahaan atau terhadap pertumbuhan pada pasar saham. Nilai perusahaan adalah harga suatu perusahaan yang bisa dibayar disaat perusahan tersebut dijual. Salah satu cara melihat nilai perusahaan adalah dengan melihat harga saham yang ada perusahaan. Ketika harga saham tinggi berarti akan tinggi pula tingkat pengembalian kepada investor dan itu berarti semakin meningkat juga nilai perusahaan jika dihubungkan dengan visi perusahaan yaitu untuk berusaha memaksimalkan keuntungan yang didapatkan oleh para pemegang saham.

Cara menghitung PBV dengan rumus :

\section{$\mathrm{PBV}=\underline{\text { harga pasar per lembar saham }}$ \\ Nilai buku saham}

\section{Profitabilitas}

Profitabilitas adalah satu yang berpengaruh terhadap kinerja manajemen yang diperlihatkan melalui laba yang dihasilkan saat mengelola aset perusahaan. Profitabilitas bisa diukur menggunakan rasio profitabilitas yang akan menunjukkan seberapa efektif perusahaan beroperasi sehingga menghasilkan keuntungan bagi perusahaan melalui rasio-rasio seperti ROE (return on Equity), ROE adalah salah satu jenis rasio profitabilitas yang memperlihatkan laba perusahaan dengan melakukan perhitungan laba bersih dibagi dengan total ekuitas perusahaan sehingga dengan rasio ini perusahaan bisa mengetahui kinerja perusahaan dalam melakukan pengelolaan terhadap modal yang ada yang diberikan kepada para pemegang saham. 


\section{Kebijakan Hutang}

Perusahaan dalam perjalanannya sering merasakan bahwa kebijakan hutang lebih baik dilakukan jika dibandingkan harus menerbitkan saham baru, sehingga saat kebijakan hutang yang dilakukan semakin tinggi maka akan tinggi pula nilai perusahaan. Kebijakan hutang dan struktur modal tidak bisa dipisahkan karena hutang adalah salah satu komponen yang ada didalam struktur modal (Darmawan, 2013) .Kebijakan hutang dilakukan oleh perusahaan untuk mendapatkan sumber pembiayaan lagi bagi perusahaan, maka kebijakan hutang adalah salah satu hal yang penting dalam penerapannya oleh perusahaan .(Rahmawati, 2012)

\section{DOL ( Degree of Operating Leverage )}

DOL (Degree of Operating Leverage ) adalah efektifitas suatu perusahaan dalam menggunakan biaya yang tetap perusahaan untuk memperoleh pengaruh dari peningkatan jumlah penjualan terhadap earning before interest and taxes (EBIT). DOL yang semakin tinggi menunjukkan risiko investasi yang tinggi juga. Perusahaan dengan operating leverage yang kecil akan memiliki risiko operating leverage yang lebih rendah. (Hardiyanti, 2012).

\section{Kerangka Berfikir dan Hipotesis}

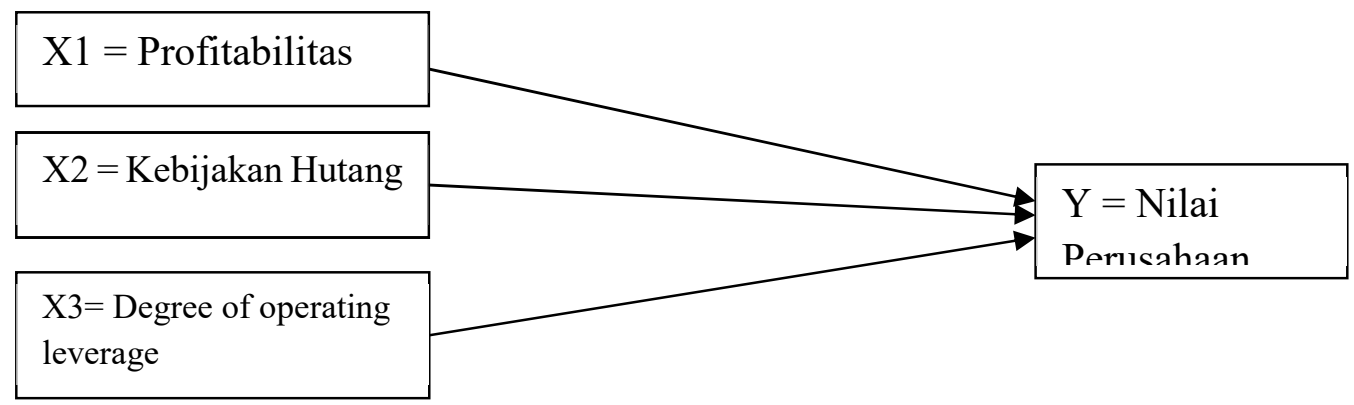

Gambar 1. Kerangka Pemikiran

Terdapat banyak faktor yang dapat mempengaruhi Nilai Perusahaan, dalam penelitian ini faktor yang digunakan sebagai variabel independen adalah Profitabilitas, Kebijakan Hutang dan Degree of operating leverage dan untuk variabel dependen yang digunakan dalam penelitian ini adalah Nilai Perusahaan.

\section{Perumusan Hipotesis}

Pengaruh Profitabilitas terhadap Nilai Perusahaan

Penelitian yang pernah dilakukan oleh (Hendrik, 2017) menghasilkan kesimpulan dengan mengatakan bahwa profitabilitas berpengaruh signifikan terhadap nilai perusahaan.

H1 : Profitabilitas berpengaruh signifikan terhadap nilai perusahaan yang terdaftar di JII 
Kesimpulan berdasarkan penelitian (Hendrik, 2017) menyatakan bahwa kebijakan hutang berpengaruh signifikan terhadap nilai perusahaan.

\section{H2 : Pengaruh Kebijakan Hutang terhadap Nilai Perusahaan yang} terdaftar di JII

Kebijakan hutang berpengaruh signifikan terhadap nilai perusahaan yang terdaftar di JII Pengaruh DOL ( degree of operating leverage ) terhadap Nilai Perusahaan Penelitian (Rexyan, 2019) memberikan informasi bahwa hasil yang didapat dari penelitiannya bahwa kebijakan hutang berpengaruh signifikan terhadap nilai perusahaan.

\section{H3 : Dol berpengaruh signifikan terhadap nilai perusahaan yang} terdaftar di JII

\section{METODE PENELITIAN}

Data dalam melakukan penelitian ini adalah dengan menggunakan data kuantitatif. Penelitian yang dilakukan terdiri dari tiga variabel independen dan satu variabel dependen, yang termasuk variabel independen adalah profitibilitas, kebijakan hutang, dol ( degree of operating leverage) dan variabel dependen adalah nilaiperusahan. Populasi dalam penelitian ini adalah Perusahaan yang terdaftar di JII Jakarta Islamic Index ). Sampel pada penelitian berdasarkan kriteria tertentu yaitu perusahaan yang berturut-turut tercatat di Jakarta Islamic Index periode juni 2016 - mei 2019. Sumber data diperoleh dari BEI ( Busra Efek Indonesia ) atau pada situs (www.bei.co.id).

Model Regresi : $\mathrm{Y}=\alpha+\beta 1 \mathrm{X} 1+\beta 2 \mathrm{X} 2+\beta 2 \mathrm{X} 3+e$

Dimana :

$\mathrm{Y}=$ Nilai Perusahaan

$0=$ Bilangan Konstansta

1,2,3 = Koefisien regresi untuk masing-masing variable independen

$\mathrm{X} 1=$ Profitabilitas

X2 = Kebijakan Hutang

$\mathrm{X} 3=\mathrm{DOL}$

$e \quad=$ Error

\section{E. HASIL DAN PEMBAHASAN}

Informasi yang diperoleh berdasarkan sampel untuk perusahaan yang terdata di JII di periode juni 2016 - mei 2019 terdapat 30 perusahaan setiap periode, yang terdaftar berturut - turut dari periode tersebut ada 17 perusahaan, dan 2 perusahaan data tidak bisa diolah. Jadi hanya 15 perusahaan yang bisa diolah dan untuk pemilihan data yang akan diolah 
pada penelitian ini adalah selama 2 tahun, maka jumlah observasi yang dilakukan di penelitian ini adalah 30 sampel.

Tabel 1 Pemilihan Sampel

\begin{tabular}{ll}
\hline Keterangan & Jumlah \\
\hline Perusahaan yang terdaftar di JII mulai Juni 2016 - Mei 2019 & 42 \\
Perusahaan di JII berturut - turut selama periode Juni 2016 - Mei & 71 \\
201 & \\
Perusahaan yang memiliki laba tahun berjalan negatif & 1 \\
Perusahaan yang terdaftar di JII yang dijadikan sampel & 15 \\
Tahun Penelitian yang digunakan & 2 \\
Data yang outlier & $(2)$ \\
\hline Jumlah Sampel Penelitian & $\mathbf{3 0}$ \\
\hline
\end{tabular}

\section{Uji Normalitas}

Untuk pengujian apakah data yang ada normal atau tidak, bisa dilakukandengan menggunakan pengujian normalitas. Pada penelitian ini uji normalitas diuji dengan pengujian 1 -sample $K-S$. Berikut ini disajikan tabel 1 yang merupakan hasil pengujian normalitas data:

Tabel 2 Hasil Uji Normalitas 1-Sample KS

\begin{tabular}{lccl}
\hline Varibel & $\begin{array}{c}\text { Asymp. Sig. } \\
\text { (2-tailed) }\end{array}$ & Standard & Keterangan \\
\hline Profitabilitas & 0,089 & $>0,05$ & Data \\
Kebijakan Hutang & 0.081 & $>0,05$ & berdistribusi \\
Degree of operating leverage & 0,080 & $>0,05$ & normal \\
\hline
\end{tabular}

Residual yang ada bisa berdistribusi normal apabila nilai signifikansi $>0,05$. Dari hasil olah data pada tabel 2 memperlihatkan bahwa residual terdistribusi normal. Hal ini ditunjukkan oleh nilai signifikansi (Asym.Sig 2-taled) $>$ dari 0,05 yaitu $0,089,0,081$ dan 0,080 .

\section{Uji Multikolinearitas}

Hasil uji multikolinearitas penelitian ini ditunjukkan pada tabel 3.

Tabel 3 Hasil Uji Multikolinearitas

\begin{tabular}{lclllc}
\hline Varibel & $\begin{array}{c}\text { Toler } \\
\text { ance }\end{array}$ & Standard & VIF & $\begin{array}{c}\text { Stan } \\
\text { dard }\end{array}$ & Keterangan \\
\hline Profitabilitas & 0,486 & $>0,1$ & 2,057 & $<10$ & Tidak terjadi \\
Kebijakan Hutang & 0,605 & $>0,1$ & 1,652 & $<10$ & Multikolinearitas \\
$\begin{array}{l}\text { Degree of } \\
\text { operating }\end{array}$ & 0,695 & $>0,1$ & 1,439 & $<10$ & \\
leverage & & & & & \\
& & & & & \\
\end{tabular}


Setelah pengujian dilakukan dapat dilihat model regresi yang dilakukan tidak bermasalah dengan multikolinearitas pada penelitian ini. Nilai toleran 0,1 dan (VIF) tidak lebih dari 10. Nilai toleransi pada variabel profitabilitas bernilai 0,486 , variabel kebijakan hutang sebesar 0,605 dan 0,695 untuk variabel dol ( degree of operating leverage ). Nilai VIF untuk variabel profitabilitas 2,057, kebijakan hutang bernilai 1,652 dan variabel dol ( degree of operating leverage ) sebesar 1,439.

\section{Uji Heteroskesdastisitas}

Tabel 4 Hasil Uji Heteroskesdastisitas

\begin{tabular}{llll}
\hline Varibel & $\begin{array}{c}\text { Asymp. } \\
\text { Sig. (2- } \\
\text { tailed) }\end{array}$ & Standard & Keterangan \\
\hline Profitabilitas & 0,076 & $>0,05$ & \\
Kebijakan Hutang & 0,967 & $>0,05$ & Bebas \\
Degree of operating leverage & 0,782 & $>0,05$ & \\
& & &
\end{tabular}

Uji heteroskedastisitas diuji menggunakan uji koefisien korelasi Spearman's rho. Berdasarkan tes ini, semua variabel memiliki nilai signifikansi lebih besar dari 0,05 sehingga dapat menyimpulkan bahwa model yang digunakan tidak terjadi problem Heteroskedastisitas. Nilai yang signifikansi untuk profitabilitas adalah 0,076 , kebijakan hutang adalah 0,967 dan 0,782 dol (degree of operating leverage)

\section{Uji Autokolerasi}

Hasil uji Autokolerasi penelitian ini ditunjukkan pada tabel 5 dengan menggunakan uji run test.

Tabel 5. Hasil Uji Autokolerasi

\begin{tabular}{lclc}
\hline Model & $\begin{array}{c}\text { Asymp. Sig. } \\
\text { (2-tailed) }\end{array}$ & Standard & Keterangan \\
\hline Unstandardized Residual & 0,193 & $>0,05$ & $\begin{array}{c}\text { Tidak terjadi } \\
\text { Autokolerasi }\end{array}$
\end{tabular}

Hasil uji autokolerasi dengan run test dikatakan tidak terjadi autokolerasi adalah jika nilai siginifikansi $>0,05$, berdasarkan hasil pada tabel nilai signifikansinya adalah 0,193 .

\section{Uji Regresi Linear Berganda}

Model regresi linear berganda 
Tabel 6 Model regresi linear berganda

\begin{tabular}{ll}
\hline Variabel & B \\
\hline Constant & 4,517 \\
Profitabilitas & 46,666 \\
Kebijakan Hutang & 4,172 \\
Degree of operating leverage & $-9,702$ \\
\hline
\end{tabular}

$Y=4,517+46,666(X 1)+4,172(X 2)-9,702(X 3)$

\section{Uji Kelayakan Model ( Uji F )}

Hasil uji kelayakan model seperti pada tabel berikut ini :

Tabel 7 Hasil Uji Kelayakan Model ( F )

\begin{tabular}{lcclc}
\hline F Hitung & $\begin{array}{c}\text { F } \\
\text { Tabel }\end{array}$ & $\begin{array}{c}\text { Signifikan } \\
\text { si }\end{array}$ & Stnadart & Keterangan \\
\hline 98,680 & $>2,96$ & 0,000 & $<0,05$ & $\begin{array}{c}\text { Model layak } \\
\text { digunakan }\end{array}$ \\
\hline
\end{tabular}

Hasil yang didapat dari pengujian ini diperoleh bahwa nilai F Hitung $>$ dari F Tabel yaitu sebesar 98,680 dan dengan tingkat signifikansi sebesar 0,000 yang $<$ dati standart . Karena tingkat signifikansi lebih kecil dari 0,05 dan F Hitung lebih besar dari F Tabel maka dapat dikatakan bahwa profitabilitas, kebijakan hutang, dan dol (degree of operating leverage) berpengaruh signifikan terhadap nilai perusahaan.

Uji Hipotesis ( Uji t )

Hasil uji Hipotesis seperti pada tabel berikut ini :

Tabel 8 Hasil Uji t

\begin{tabular}{lcll}
\hline Varibel & $\begin{array}{c}\text { Asymp. Sig. } \\
\text { (2-tailed) }\end{array}$ & Standard & Keterangan \\
\hline Profitabilitas & 0,000 & $<0,05$ & Diterima \\
Kebijakan Hutang & 0,019 & $<0,05$ & Diterima \\
Degree of operating leverage & 0,001 & $<0,05$ & Diterima \\
\hline
\end{tabular}

Hasil uji t dapat dilihat pada tabel 6, jika signifikansi $<0,05$ maka Ha diterima. Uji $t$ ini dilakukan supaya kita bisa melihat ada atau tidak pengaruh dari variabel independen yang ada terhadap variabel dependen pada penelitian. Berdasarkan tabel 6 hasil uji $t$ menunjukkan sigifikansi pada semua variabel $<0,05$ yaitu profitabilitas signifikansi sebesar 0,000 , kebijakan hutang signifikansi sebesar 0,019 , dol ( degree of operating leverage) signifikansi sebesar 0,001, maka hipotesis diterima, Jadi dapat disimpulkan bahwa profitabilitas, kebijakan hutang, dol ( degree of operating leverage) berpengaruh signifikan terhadap nilai perusahaan. 


\section{Uji Koefisien Determinasi}

Untuk mengetahui besarnya pengaruh profitabilitas,kebijakan hutang, dan dol ( degree of operating leverage ) terhadap nilai perusahaan dilakukan analisis terhadap koefisien determinasi. Hasil pengujian tersebut dapat dilihat pada :

Tabel 9. Hasil uji koefisien determinasi

\begin{tabular}{cc}
\hline Model & R2 \\
\hline Nilai Perusahaan & 0,910 \\
\hline
\end{tabular}

Berdasarkan tabel diatas nilai koefisien determinasi (R2) menunjukkan jumlah 0,910 atau $91,0 \%$ dari nilai perusahaan dipengaruhi oleh profitabilitas, kebijakan hutang, dan dol ( degree of operating leverage ). Sisanya sebesar $10,0 \%$ dipengaruhi oleh faktor-faktor lain yang tidak diamati dalam penelitian ini.

\section{E. PENUTUP}

Dari data yang diperoleh pada penelitian ini didapat populasi yang dilakukan yaitu pada perusahaan yang masuk di JII dengan rentang periode juni 2016 - mei 2019, Didapat 30 sampel yang bisa dilakukan pengolahan data dengan kriteria perusahaan tersebut terdaftar secara berturut - turut selama periode yang ada, hasil dari penelitian yang telah dilakukan pengujian menjelaskan bahwa profitabilitas, kebijakan hutang, dan dol ( degree of operating leverage ) berpengaruh signifikan terhadap nilai perusahaan yang terdaftar di JII. Jadi jika nilai perusahaan yang ada semakin tinggi akan menimbulkan keinginan investor untuk dapat berinvestasi pada suatu perusahaan. Penelitian ini memiliki keterbatasan yang dapat memperlambat hasil penelitian yaitu saat pengambilan data berdasarkan populasi di JII, setiap periode hanya 30 perusahaan yang tercatat, dan untuk periode selanjutnya perusahaan yang masuk di periode sebelumnya belum tentu masuk pada periode selanjutnya , bahkan tidak masuk karena digantikan oleh perusahaan yang lain. Untuk penelitian selanjutnya,diharapkan dapat menggunakan populasi yang lain yang lebih luas , supaya pengambilan sampel akan lebih mudah dilakukan oleh peneliti.

\section{DAFTAR PUSTAKA}

Analisa, Y. (2011). Pengaruh ukuran perusahaan, leverage, profitabilitas dan kebijakan dividen terhadap nilai perusahaan. Skripsi. Semarang: Universitas Diponegoro. Akuntansi.

Darmawan, W. A. (2013). Analisis Pengaruh Kebijakan Hutang, Profitabilitas dan Kebijakan Dividen Terhadap Nilai Perusahaan (Pada Perusahaan Manufaktur Yang Terdaftar di BEI Periode 2009-2011). Universitas Semarang. 
Hardiyanti, N. (2012). Analisis Pengaruh Insider ownership , Leverage, Profitabilitas , Firm size dan Dividen Payout Ratio Terhadap Nilai Perusahaan (Studi Pada Perusahaan Manufaktur Yang Terdaftar di BEI Tahun 2007-2010.

Hendrik. (2017). Pengaruh Profitabilitas Dan Kebijakan Utang Terhadap Nilai Perusahaan Yang Terdaftar di Jakarta Islamic Index (JII). Akuntansi, Vol 2 no 1.

Meckling, J. d. (1976). Teori Keagenan.

Rahmawati, A. N. (2012). Analisis Faktor Kebijakan Hutang Yang Mempengaruhi Nilai Perusahaan (Studi Pada Perusahaan Manufaktur Yang Terdaftar di BEI Periode 2006-2010). Skripsi Program Sarjana Fakultas Ekonomi dan Bisnis Universitas Diponegoro.

Saputra, A. J. (2018). Pengaruh Minat, Motivasi, Pelatihan Profesional, Gender, Lingkungan Pekerjaan Terhadap Pilihan Karir Akuntan. JAD: Jurnal Riset Akuntansi \& Keuangan Dewantara, 1(2), 67-76. 